\title{
Translating the Marseillaise: Biblical Republicanism and the Emancipation of Jews in Revolutionary France
}

Ronald Schechter

William \& Mary, rbsche@wm.edu

Follow this and additional works at: https://scholarworks.wm.edu/aspubs

Part of the European History Commons

\section{Recommended Citation}

Schechter, Ronald, Translating the Marseillaise: Biblical Republicanism and the Emancipation of Jews in Revolutionary France (1994). Past \& Present, 143(1), 108-135.

https://doi.org/10.1093/past/143.1.108

This Article is brought to you for free and open access by the Arts and Sciences at W\&M ScholarWorks. It has been accepted for inclusion in Arts \& Sciences Articles by an authorized administrator of W\&M ScholarWorks. For more information, please contact scholarworks@wm.edu. 
On 21 October 1792 the Jews of Metz joined their Gentile compatriots in celebrating a republican victory. Emancipated by the Constituent Assembly only one year previously, the newcomers to French citizenship took the occasion of a civic festival to celebrate their recently won freedom. Testimony to this public show of Jewish patriotic zeal is an extraordinary document, a Hebrew version of the "Marseillaise," which the "citizens professing the faith of Moses" sang to republican soldiers in the synagogue of Metz. There was nothing blasphemous in the patriotic hymn, and indeed the Jews were following an ancient tradition by praying for the land to which they had been dispersed. For the period of the Revolution, however, it was an unique event, and as such provides the historian with a rare opportunity to glimpse into the world of French Jewry on the morrow of its emancipation. One sees in the Hebrew "Marseillaise" a Jewish attempt to understand the staggering events of Revolution and emancipation, to comprehend the historical situation in which they suddenly found themselves, to articulate their relationship to the nation and to sacralize the Revolutionary values of their patrie. By placing the Hebrew battle hymn and its French translation in the context of Revolutionary demands vis-àvis the newly emancipated Jews, one perceives the power of republican ideas such as indivisibility, fraternity, and regeneration to penetrate even into the long-isolated world of orthodox Jewry, and the attempt of a traditional people 
to embrace the values of its liberators without losing its ancient identity. By singing a Hebrew version of the republican hymn, the Jews of Metz found a "traditional" means of identifying with France's struggles, of integrating themselves mentally into the French nation, in short, of picturing themselves as Frenchmen.

The fête civique began at ten o'clock in the morning, when the representatives of the commune of Metz assembled to celebrate the recent successes of the Republican Army in Savoy. Escorted by a company of Sexagenarian veterans, they left the communal house and marched to the Departmental Assembly, where they joined the administrative corps, the magistrates, the heads of the National Guard, leaders of the garrison and the citizen-soldiers of Thionville, who in a decisive battle had recently driven the enemy from their town and saved their compatriots in Metz from an otherwise imminent siege.

Two canons, provided by the National Guard and drawn by artillery horses, were then fired, signalling the beginning of the procession. Military sounds continued in the form of drum-roll and music performed by various corps of soldiers, who marched with public functionaries, judges and civilians along with their comrades, the volunteers of Thionville. A model of fraternity, the citizens marched in no apparent order of precedence, and mixed irrespective of 
status under the banner of the département, carried by the senior member of the Veterans' Company. 1

At the sound of church bells, three hundred members of the National Guard joined the parade. They marched to the rousing strains of the "Marseillaise" and the "Ça Ira," frequently interrupted by the applause of participants and the firing of artillery from the city ramparts. As the triumphant cavalcade made its way through Metz its participants traversed a space defined by such edifying points as the place de la Liberté, the place de la Loi, and finally the place de l'Égalité. The lesson in citizenship continued as the patriots encountered a large platform, erected at the height of twenty steps, and surrounded by the symbols of the Republic. A column surmounted by a cap in the style of William Tell stood next to a statue of Liberty, which in turn was adorned with the emblems of Unity, Strength and Equality.

The members of the administrative corps and the Thionville deputation mounted the platform, and an unnamed citizen made an imploring, frightening speech, brimming with republican rhetoric about an "impious league" headed by a "conspirator king and perjurer," an enemy of Liberty

1. Procès-Verbal dressé par les Représentans de la Commune, de la fête célébrée à Metz, en réjouissance du succès des Armées de la République en Savoie. Du 21 octobre 1792, l'an premier de la République, [Metz, 1792]. 
and "assassin" of the Constitution. This false sovereign, warned the speaker, invited his subjects to "sleep peacefully on the edge of a volcano about to erupt beneath you." Following the speech, Citizen Duprat, the commander of Thionville, increased the dramatic tension of the moment as he drew his sword, pointed proudly to the scar he had "earned" in battle, then placed his weapon at the foot of the emblems of Liberty and Equality. The commander's heroic gesture provoked thunderous applause and shouts of "Vive la République!" from the throngs of citizens crowding the place de l'Égalité. The orchestra once again struck up the "Marseillaise," and the good citizens of Metz and Thionville sang the chorus of each strophe.

In many respects the fête civique at Metz resembled the hundreds of other Revolutionary festivals taking place throughout France during the decisive year of 1792 .

Conforming to the typology of a fête révolutionnaire, the festival at Metz included all of the obligatory features: the fraternization among groups distinguished solely by their "function," the patriotic speeches, the playing of the "Marseillaise" and the firing of artillery, and the exhibition of national emblems, those holy relics of the Republic. 2 What was unusual, and indeed unique in the Metz festival was the organized participation of Jews.

2. Mona Ozouf, Festivals and the French Revolution, trans. Alan Sheridan (Paris: Gallimard, 1976). 
Established in 1567, the Jewish community of Metz had grown by the end of the eighteenth century to comprise three thousand inhabitants. Although socially and economically inferior to their Sephardic coreligionists in Bordeaux, under the old Regime the Jews of Metz possessed a superior legal status to that of their poor relations in the communities of Alsace and Lorraine. They enjoyed the right to reside in the city, to lend money legally at interest rates determined by the royal authorities, to govern their religious and civil activities, and, significantly, to participate as a corps in ceremonies marking important dynastic occasions. Practiced in the tradition of patriotic acclamation, the Jews of Metz were eager to demonstrate their loyalty to the nation that had finally accepted them as equal citizens. 3

Their Gentile compatriots were quick to show their appreciation. At three in the afternoon, after a spartan meal at the Commune and a Te Deum service at the Cathedral, the members of the Departmental Assembly returned to the Maison commune, where the president addressed the representatives and, on behalf of the city's recently emancipated Jews, invited them to the synagogue to join

3. Robert Badinter, Libres et Égaux...L'émancipation des Juifs 1789-1791. (Paris: Fayard, 1989), 38-39; Patrick Girard, La Révolution française et les Juifs (Paris: Robert Laffont, 1989), 31 . 
their compatriots in prayer. "Citizens," he announced, "You have just rendered thanksgiving unto the Eternal, who poured out his blessings upon the just cause and the armies who defended it. The citizens professing the Religion of Moses are also going to present their grateful homage to the mighty God, the God of Armies. They have invited you [to join them]; let us go eagerly, for the difference in religion does not constitute a difference in love for the Republic."

After leaving the Maison commune, the defenders of Thionville were greeted by the chief rabbi, Oury Cahen, who accompanied them to the synagogue. There they met the Jews of Metz, who were waiting in full festival dress for the solemn ceremony about to take place. The rabbi led the soldiers before the tabernacle and made an "extremely patriotic speech, exalting the bravery of the defenders of Thionville, emphasizing that France had the right to count on the efforts of all her children, no matter what their faith."4 Next, the rabbi presented Rolly, the mayor of Metz, with a civic crown. Following this rite of civic recognition, an orchestra struck up the "Marseillaise," but instead of hearing the familiar lyrics of Rouget de Lisle,

4. Archives israélites 3 (1842): 571-572. 
the victors of Thionville heard a strange, incomprehensible rendition of the battle hymn: 5

naflah naflah malchut ha-resha cherem hi utehi toeva

Fallen, fallen is the wicked reign, The abomination has been banned.

For an additional thirty stanzas the Jews celebrated in their sacred language the revolutionary events that had made them free. "Our fetters have been cut off; they have burst," the Jewish citizens sang in Hebrew, "The crushing

5. [Moïse Ensheim], La-Menatseach Shir le-Moshe Ensheim, Metz, [1792]. "Ce cantique...chanté le 21 octobre [1792]..., dans la synagogue de Metz, sur l'air de la Marseillaise, se ressent, quant au contenu, de l'exaltation politique de l'époque." Archives israélites 1 (1840): 35. Although no contemporary document confirms the report that Ensheim's canticle was sung to the tune of the "Marseillaise," the claim is made probable by the fact that over two hundred songs of the French Revolution, including an "actors' song" at the Metz festival, were sung to the tune of the "Marseillaise." Constant Pierre, Les Hymns et chansons de la Révolution française (Paris: Imprimerie nationale, 1904). 
oppression has ceased." This liberation, however, was in danger, as "the kings of the earth have come together to put us in slavery." In an apocalyptic description of the revolutionary battles, the Jews depicted the arrival of enemies as "a holocaust coming from the distance." Thus they urged their fellow citizens:

Arise, volunteers of the people!

Take courage and act as men. You have a sword, a sword of vengeance. A sword of the equal and free.

The congregation went on to threaten the "arrogant ones" for whom there was "no hope." "The end is coming," they sang. "Tremble at every moment!"6 Similarly, enemies at home were chastised, "Be ashamed and confounded of your ways, / You who sow discord among brothers." Aristocratic despoilers of the nation, those "who wear cloaks of fur," and who "abandon [their] good name by making false oaths," were similarly warned, "Your sins will not be erased." Next the newly emancipated Jews used Solomonic language to praise the wise legislators who had emancipated them:

The wise men of the nation have assembled.

6. Cf. the "Marseillaise," "Tremblez tyrans!" 
They will instruct us in the laws of righteousness. They will make the nation stand in justice. And they will guide us on the paths of righteousness.

The arrival of the enlightened lawmakers, the tsadikim (righteous ones), was the event by which the emancipated Jews defined two historical epochs. "Before them" was an age in which "Death governed in anger," granting his favor "to whomever he pleased." Injustice reigned as "a man worked on his field / while the one who did not work ate of his fruit," Since the arrival of the righteous, however, each man "will be sated with the fruit of his labor. / For the voice of the taskmaster is no more." The old Regime was depicted as a time when "the people were trampled underfoot" and "officials took whatever they desired." By contrast, "Today the heart of the brave man will not fail / For the compassionate ones have arrived." While these verses apply equally to the history of the Jews and the history of the French, one stanza in particular epitomizes the sense of Jewish history as it was understood at that moment :

House of Jacob! You have suffered so. You fell through no fault of your own. Away with your sadness, for there is a future. Behold the day of redemption, the year of salvation! 
The Jewish citizens continued their song with a promise of loyalty to the nation and its laws.
Arise, brothers! Recount the law!
Take courage! Do as the law prescribes!
The law of the land is our protection.
For we have entered into a covenant of brotherhood.

They appealed to the "inhabitants of the land," the "witnesses" at the "altar of the covenant between us," and promised never to betray their trust. They lauded the legislators of France, the "men of integrity" who would be remembered by posterity. "Behold! You have established a monument unto yourselves," they sang. "Your fame will be eternal like the moon." Finally, the ode concluded with a benediction on the French nation:

Blessed be you! Land of France. Blessed be you! Protect the soil in all your struggles. Your justice dwells in peaceful tranquility, Strength and trust in your children's arms.

The patriot-soldiers of Thionville must have been mystified by this curious version of the "Marseillaise," composed in Hebrew by Moïse Ensheim, but it is likely that they had access to the French translation of Isaïah Berr 
Bing. ${ }^{7}$ Following the tradition of Jewish patriotic liturgy in France, the notables of the community published a translation of the Hebrew original, and it is reasonable to believe that the French text had been distributed or posted in some form on the day of the celebration. 8 We shall analyze the French version later in this essay, but a real understanding of Bing's translation is only possible following a discussion of the Hebrew original, which is essential to any investigation of how the Jews construed the Revolutionary situation in which they suddenly found themselves.

To comprehend the Revolution was an arduous task for the Jewish community of Metz. Jacob Katz has described the Jews of pre-revolutionary Europe as a "traditional society" who showed a "total reliance on the distant past" for their

7. Cantique composée par le Citoyen Moyse Ensheim, à l'occasion de la fête civique célébrée à Metz, le 21 octobre, l'an 1er de la République, dans le Temple des Citoyens Israëlites, [trans. Isaïah Berr Bing], Metz, [1792].

8. The procedure at the Jewish celebration of the dauphin's birth in 1731, for example, at which a canticle had been composed and performed for the occasion, was to display banners with both Hebrew and French versions of the song. $\mathrm{Ab}$ [raham] Cahen, "Une Fête nationale à Metz," La Vérité israélite 8 (1862): 372-377. 
laws, beliefs and practices. 9 Republicanism, drawn to a large extent from classical antiquity but transformed by the ideas of the philosophes, belonged to an alien tradition. An additional barrier to Jewish comprehension of Revolutionary values was the fact that most Jews did not understand French, 10 and the Hebrew language of the late eighteenth century was ill-equipped to articulate the principles of republicanism. It lacked the vocabulary to express the sacred notions of "citizen" and "republic," and possessed no terminology for describing the enemies of republicanism: "despots" "tyrants," and "aristocrats."

To compose a republican hymn in the ancient language of the Bible was a task that required a knowledge of both the Jewish and French traditions. Moïse Ensheim, the composer of the Hebrew "Marseillaise," was one of the few members of his community who had obtained a liberal education. Born in 1750 to a poor family, Ensheim received

9. Jacob Katz, Out of the Ghetto: The Social Background of Jewish Emancipation, 1770-1870 (Cambridge: Harvard University Press, 1973), 6. 10. Nearly all the Jews of Eastern France spoke exclusively Judeo-Alsatian, a particular branch of Yiddish whose vocabulary was seventy percent Germanic, twenty percent Judeo-Aramaic and less than ten percent French. Bernard Blumenkranz, Histoire des Juifs en France (Toulouse: Privat, 1972), 172. 
a traditional Jewish education, which was evidently insufficient for the autodidact's needs, as he went on to teach himself French and German, the classical languages and even Arabic. A considerable mathematician, he worked in Berlin as preceptor for Moses Mendelssohn's children between 1782 and 1785. In Berlin Ensheim came into contact with the group of Enlightened Jewish intellectuals known as the maskilim, led by Mendelssohn, and Ensheim made several contributions to the group's Hebrew journal, Ha-Meassef. His first patriotic poem, in honor of the National Assembly, was published in 1790.11 In addition to his activities as a poet, Ensheim was involved in the polemics surrounding the Jewish question before and during the Revolution. He aided Abbé Grégoire in his famous Essai sur la régénération physique, morale et politique des Juifs, and was consulted by the defender of French Jewry during the emancipation debates in the National Assembly. ${ }^{12}$

Steeped in the enlightened philosophy of Mendelssohn and the Berlin maskilim, literate in the language of the patrie, and well-versed in the science and philosophy of

11. Ha-Meassef (1790): 33-37.

12. Heinrich Graetz, Geschichte der Juden, 11: 135-136, 210; Jonathan I. Helfand, "The Symbiotic Relationship between French and German Jewry in the Age of Emancipation," Leo Baeck Institute Year Book XXIX (London: Secker \& Warburg, 1984), 334-335. 
his century, Ensheim was one of the few members of his community capable of interpreting the revolution for his coreligionists. It would be misleading, therefore, to suggest that the hymn sung by the Jews in the synagogue at Metz was "representative" of a popular Jewish view of Revolution. Such a view did not exist at the time, as the traditional culture of Jewish orthodoxy was desperately ill-equipped to interpret the radically new situation of Revolution. A Jewish interpretation of Revolution had to be invented, and only certain rare figures, inhabitants at the same time of the Jewish world and the French, were capable of such a task.

Thus Ensheim's ode served a didactic function. It was meant to make the bewildering events of Revolution and emancipation comprehensible to those Jews who understood their own heritage but remained ignorant of eighteenthcentury secular values and unversed in the idiom of Enlightenment. But how was it possible to explain essentially foreign ideas in a language that itself lacked both the vocabulary and imagery of republicanism? Ensheim compensated for this deficiency with a wealth of Biblical references, allusions and metaphors. By making use of images that were both familiar and sacred, the author of the Hebrew "Marseillaise" created a Jewish iconography of Revolution. 
In order to comprehend the Revolution, it was first necessary to understand what had preceded it. A republican sense of history had to be created, and for this a picture of the "Old Regime" was necessary. The first verse of the canticle proclaims the fall of a "wicked reign [malchut haresha]," and in so doing depicts the monarchy as something morally repugnant to God. The same line also alludes to a more specific and vivid image of evil rule. The exclamation, "Fallen, fallen is the wicked reign [naflah naflah malchut ha-resha]" alludes unmistakably to Isaiah's exclamation, "Fallen, fallen is Babylon [naflah naflah bavel]."13 Babylon, synonymous in this context with luxury and corruption, is an apposite metaphor for the hated old Regime, as it happily confirms the republican indignation with the assurance that such a regime is detestable in God's eyes. It implies the sin of idolatry, which Ensheim refers to more directly in a later passage: "Behold, the altar of $\mathrm{Ba}$ 'al has been broken down!"14 This is a literal quotation from the book of Judges, and describes Gideon's destruction of the Canaanite altar, but Ensheim transforms it into a cry of triumph over the fallen monarchy. By equating monarchy with idolatry, the composer implies that the king had arrogated the power of God. Like the Babylonian king in the book of Isaiah, he dared to consider

13. Isa. 21:9.

14. hineh nutatz mizbeach ha-ba'al, Judg. 6:28. 
himself a "shaker of the Earth [margiz ha-aretz]" and liken himself to the Almighty. 15

This sort of arrogance, Ensheim warns, is inevitably punished on the "day against the proud and lofty [yom al ge'eh $v$-ram]."16 When the chorus in synagogue sings, "The crushing oppression has ceased [shavta shavta ha-madheva]," the implication is that divine intervention is responsible. The reference is to Isaiah's prediction of Israel's return from Babylonian exile. At that time, according to the prophet, the Jews would taunt the king with the exclamation, "How the taskmaster has ceased, the crushing oppression has ceased."17 God himself would be responsible for the overthrow of oppression, as the following two verses of the Isaiah's prediction reveal: "The Lord has broken the staff of the wicked, the scepter of rulers, that smote the peoples in wrath with unceasing blows, that ruled the nations in anger with unrelenting persecution."18 In Ensheim's hymn, then, the republican troops are merely the vehicle of divine retribution, and patriots have the right to threaten the enemies of Revolution with language that Ezekiel's God used against Pharaoh: "Tremble at every

15. Isa. $14: 16$

16. Isa. 2:12.

17. ech shavat nogesh shavta madheva, Isa. 14:4.

18. Isa. 14:5-6. 
moment!"19 The enemies of liberty are enemies of God, and the fight against tyranny is sanctioned by the Almighty himself.

Thus a vivid depiction of the old Regime and its inevitable demise emerges. A hateful reign -- arrogant, luxurious and oppressive like Babylon, idolatrous like Canaan, despotic like Pharaonic Egypt -- is overthrown by an indignant God. Nevertheless, while Ensheim's canticle celebrates the death of tyranny, it continues to warn that enemies threaten the successes of Revolution. In this way it explains the recent battles against "the kings of the earth" who have "come together to put us in slavery." In order to represent France's current struggles, ancient images of Biblical battles against evil are resuscitated. When the congregation sings its praise to the "volunteers of the people [ha-mitnadvim ba-am]," it recalls the Hebrew warriors who fought in the conquest of Canaan, and to whom Deborah sang her praises. 20 And the words of encouragement to the troops, "The heart of a brave man will not fail," echo David's words to Saul before the young fighter set out to slay Goliath. 21

Just as France's current battles resemble Israel's ancient struggles, so they also coincide with the

19. chirdu li-rgayim, Ezek. 32:10.

20. Judg. 5:9.

21. al yipom lev ish chayal Cf. 1 Sam. 17:32. 
apocalyptic battles to take place at the end of time. Thus the war against the nation's enemies appears to be the fulfillment of ancient prophesies. When the chorus sings of the enemy "like a holocaust coming from the distance [ka-shoa mi-merchak tavo]," it recalls Isaiah's prediction of God's wrath against Israel as punishment for injustice. 22 There seems to be some inconsistency in the use of this reference, as it implies that God's wrath is directed against France, who, like the Israel of Isaiah's diatribes, is deserving of punishment. Similarly, the verse, "The enemies came from the North," alludes to Jeremiah's prediction of the destruction of Babylon.23 Perhaps Ensheim

22. The entire reference is: "Woe to those who decree iniquitous decrees, and the writers who keep writing oppression, to turn aside the needy from justice and to rob the poor of my people of their right, that widows may be their spoil, and that they may make the fatherless their prey! What will you do on the day of punishment, in the holocaust coming from the distance?" Isa. 10:1-3. 23. me-tsafon bau ha-shodedim, cf. Jeremiah: "The enemies will come against her from the North [metsafon yavo-lah hashodedim]." The complete reference is: "Therefore, behold, the days are coming when I will punish the images of Babylon; her whole land will be put to shame, and all her slain will fall in the midst of her. Then the heavens and the earth, and all that is in them, will sing for joy 
wanted to depict the foreign invasions as a kind of divine punishment for France's previous sins. There is a danger, however, in such a literalist interpretation. It seems more likely that Ensheim deliberately took the prophetic references out of their original context to give an apocalyptic gravity and a sense of sacred destiny to the current national struggle. Moreover, like the prophesies themselves, their recapitulation held out the promise that the apocalyptic battles would be followed by messianic peace.

Meanwhile, however, the enemy remained. As in typical republican portrayals, the antagonist was not easily recognizable as a soldier in a foreign army. The most dangerous enemy was the elusive but ever-present "aristocrat" plotting the overthrow of liberty. But how was a republican notion of aristocracy to be assembled out of traditional Jewish images? Ensheim responded to this challenge by designating the aristocrats as "those who wear fur cloaks [ha-lovshim atseret shear]." This image has a double meaning, as it signifies not only the decadent luxury of aristocratic life, but alludes as well to deception and conspiracy. Ensheim borrows the symbol from Zechariah, who railed against false prophets for wearing

over Babylon; for the enemies will come against her from the North, says the Lord." Jer. 51:47-48. 
fur cloaks "in order to deceive."24 Ensheim embellishes upon the theme of deception by claiming that these fur-clad conspirators, like the hypocritical courtiers in the book of Proverbs "with a flattering mouth make ruin." 25 They "abandon their good name by making false oaths", 26 and for this crime receive the same curse that Nehemiah used against those who mocked his efforts to rebuild the walls of the ancient Temple, "Your sins will not be erased."27 Through his combination of Biblical metaphors, Ensheim creates a vivid picture of a detestable aristocracy. These are aristocrats of a republican imagination: deceitful, conspiring, flattering and hypocritical. But Ensheim's description contains an element that is missing from typical republican depictions of the aristocratic enemy: namely, the assurance that these men are repugnant in God's eyes. They are sinners who will never be forgiven.

Ensheim opposed the picture of the aristocrat to that of the good citizen. Representing the classical notion of citizenship in the language of the Bible was a task that required imagination. The Hebrew sign that most approximated the French citoyen was yoshev ha-aretz (inhabitant of the land), but this appellation was a poor

24. Zech. 13:4.

25. u-vpeh chalak ya'asu midcheh, Prov. 26:28.

26. hen shimchem li-shvuah tanihu

27. chatatchem lo timacheh, Neh. 4:5. 
substitute, as it connoted none of the values implicit in the French concept. Ensheim responded to this difficulty by reducing the complex notion of "citizen" to its simpler components. Although lacking a Hebrew equivalent for the sacred republican idea, the composer of the Hebrew "Marseillaise" showed himself to be quite familiar with the composite of traits that Simon Schama has named "the cultural constitution of a citizen."28 Among the most celebrated of these virtues was sensibilité, "the intuitive capacity for intense feeling." 29 A good citizen had to possess a "sensitive heart." Ensheim's text is accordingly full of references to the heart (lev). In his depiction of legislative sensibilité, Ensheim praises the lawmakers of France as "the people of the wise hearts [amim chachmei lev]." As opposed to those who rely simply on cold calculation, the representatives are moved by their emotions, "For their heart is not hidden by their intellect."30 Sensibilité is not only a virtue of citizenship; it is a precondition for good government. Thus the chorus asks God rhetorically, "And who will govern

28. Simon Schama, Citizens: A Chronicle of the French Revolution (New York: Alfred A. Knopf, 1989), 123-183. 29. Schama, 149.

30. ki libam lo nitspan mi-sechel. 
the birth of nations / If you have not given him a listening heart?"31

Closely related to sensibilité was the republican virtue of transparency. Lynn Hunt has emphasized the necessity of this virtue in the logic of republican ideology. A truly indivisible nation could only be created if all barriers between citizens were broken. National unity depended upon "the abolition of the distance between citizen and citizen and between individual and community."32 A "sensitive heart" was insufficient if it was not fully visible to one's compatriots. In practice, however, there was no guarantee against deception and hypocrisy. A true "aristocrat" was capable of breaking even the most solemn oath to the nation, and this possibility intensified the popular fear of conspiracy. Ensheim's hymn recognizes the limited capacity of human beings to recognize deception, but it provides a solution in the traditional image of a God who sees into the human heart. His coreligionists sing,

Upon all actions whether good or evil,

31. u-mi yishpol reshit amim / bilti titcha lo lev lishmoa 32. Lynn Hunt, Politics, Culture, and Class in the French Revolution (Berkeley: University of California Press, 1984), 44-45. Cf. Jean Starobinski, Jean-Jacques Rousseau: La Transparence et I'obstacle (Paris: Gallimard, 1971). 
Man will see with his eyes.

Whether truth or falsehood the heart possesses, God will observe from Heaven. 33

The ideal of transparency had a special significance in regard to the Jews, as popular beliefs portrayed the Jew as thoroughly opaque. Even Abbé Grégoire, the great defender of Jewish rights, characterized the "unregenerated" Jew of his day as practiced in the art of concealing his real intentions. Referring to the supposed rabbinic justification for opacity, Grégoire writes, "A multitude of their casuists authorize...bad faith, equivocation, mental restrictions, hypocrisy." "Is it true," he asks, reserving judgement on the answer, "that, according to the Talmud, a Jew must greet a Christian by cursing him, and wish him a bon voyage while adding, under his breath, 'like that of Pharaoh in the sea..?'"34 What the Jew says under his breath, however, is no less a

33. al kol ma'aseh im tov im ra / ha-adam yireh la-einayim / ha-emet im sherek yinchal lev / yivchon ha-yoshvi bashamayim. Cf. 1Sam. 16:7, "...for the Lord sees not as a man sees; man looks on the outward appearance, but the Lord looks on the heart."

34. [Abbé Henri] Grégoire, Essai sur la régénération physique, morale et politique des Juifs (Paris: Flammarion, 1988), 87-88. 
mystery to his Christian neighbors than what he says aloud, since he speaks an incomprehensible language. The very speech of Jews renders them suspicious, and Grégoire assures his readers that before they can be regenerated it will be necessary "to extirpate this sort of slang, this tudesco-hebraico-rabbinic jargon which the German Jews use, which is only intelligible to them, and which serves only to thicken their ignorance or to hide their cheating."35 It is not an accident that debates on the Jewish right to citizenship also included discussions of the status of actors and executioners. 36 Like the traveling comediens, Jews were known as suspicious outsiders, masked pretenders and professional liars.37 Like the veiled hangman, the Jew was a frightening enigma, an eternal, if necessary, evil.

35. Grégoire, 153.

36. Archives Parlementaires, 23 December 1789.

37. It is significant, in this regard, that the city of Nancy exluded both Jews and actors from participation in the National Guard. The ban provoked a lively polemic in which authors debated the relative merits of exclusion and inclusion of actors and Jews. M. Valois, Apologie de I'opinion de M. Ranxin, sur cette question: Les Juifs doivent-ils être admis dans la Milice Nationale? [Nancy, 1790]; Lettre d'un citoyen, aux Gardes-citoyens de la ville de Nancy, en réponse de cette question: Les Juifs doiventils être admis dans la Milice Nationale? [Nancy, 1790]; 
Transparency, then, possessed a double meaning for Ensheim and the Jews of Metz. It was not only a republican value, but an indispensable condition for Jewish regeneration. At this point it is instructive to review Grégoire's theories. In his famous Essai sur la régénération physique, morale et politique des Juifs, 38 the abbé characterizes the Jews of France as unscrupulous usurers and avaricious traders who "ruin honest laborers." The rootless Jew, according to Grégoire, is at home

[Jacob Berr], Réflexions sur Lettre d'un citoyen, aux Gardes-citoyens de la ville de Nancy, en réponse de cette question: Les Juifs doivent-ils être admis dans la Milice Nationale? [Nancy, 1790]; Ma façon de penser sur l'inadmission des comédiens à la garde citoyenne de la ville de Nancy. [Nancy, 1790]; Adresse de remerciement, de la part des comédiens de la ville de Nancy, à l'auteur enroué, borgne et bossu de l'écrit intitulé: Ma façon de penser sur l'inadmission des comédiens à la garde citoyenne de la ville de Nancy. [Nancy, 1790]. It is also worth noting that actors participated at the civic festival of 21 October 1792 in Metz, and that they sang their own version of the "Marseillaise." Procès-Verbal. See note 5 above. 38. The Essai was Grégoire's award-winning response to the question posed by the Royal Society of Arts and Sciences in Metz in 1787: "Are there means of making the Jews happy and more useful in France?" 
nowhere, and thus does not have the "national spirit" necessary for citizenship. He feels no remorse about lying to the Christian, whom he despises and curses, but on the contrary considers deception and hypocrisy to be sanctioned by his religion. What separates Grégoire from the most zealous anti-semites, then, is not the belief that their accusations against Jews are untrue, but the contention that Christians, through their persecution of this unhappy people, are responsible for the level to which Jews have sunk, and that they can reverse the process. They can "regenerate" the Jews by treating them as brothers and citizens. Equal access to the trades and professions, the right to own and cultivate land, permission to serve in the armies of the patrie, these measures would raise the Jew to the level of his Christian compatriots. The opportunity, indeed the duty, to send their children to state schools would enable a new generation of young Jews to escape the casuistry of ignorant and superstitious rabbis, to learn European science and philosophy, and to replace the debased jargon of their parents with the noble and elegant language of the patrie.

The advocates of Jewish emancipation, above all the Jews themselves, found in Grégoire's writings the theoretical justification for Jewish citizenship. Even the Jews believed that they were a "degenerate" people, but blamed centuries of persecution for their current "vices," 
and insisted that citizenship would improve them.39 Ensheim was familiar with Grégoire's ideas regarding the civic and moral improvement of the Jews, 40 and accordingly tried to indoctrinate his coreligionists. He epitomized the law of degeneration in the following verse:

Even the heart of the lion and the wild animals Will break when the soul is in fetters.

Thus will man's wisdom disappear.

His heart will melt and flow like water. 41

The corollary to this principle, the law of regeneration, similarly found its expression in Ensheim's song:

As the sun with healing in its wings

Shines on a surfeit of water,

So the nation's cure is a sunny day

39. See, for example, [Mayer-Marx et al], Pétition des Juifs établies en France, adressée à l'Assemblée Nationale, le 28 janvier 1790, sur I'ajournement du 24 décembre 1789. n.p., [1789] .

40. See note 12 above.

41. gam lev arieh u-pritz chiot / yipol yom nafshu binchushtayim / af chachmat adam titvala / temes yaheloch libo ka-mayim 
Where honest love flames in the hearts of the righteous. 42

The Hebrew language of Ensheim's day did not contain an equivalent for the eighteenth-century idea of "regeneration." The author compensated for this lack with the word rifut, literally "cure." Like régénération, the term rifut connoted clinical objectivity. It attached no blame to the "degenerate" people, who merely suffered from a kind of illness that the nation, like a "sunny day," could cure. Ensheim drew the metaphor of a curative sun from the prophet Malachi, who in God's name promised the faithful of Israel, "But for you who fear my name the sun of righteousness will rise with healing in its wings."43

The image of a sun with "healing in its wings" was especially meaningful to the emancipated Jews, as it alluded to the healthy, outdoor work that utopianists like Grégoire considered salutary for the Jews, who were supposed to be as physically in need of regeneration as they were morally and politically. For Grégoire, as much a physiocrat as a romantic, the best "medicine" for the Jews was to quit their commercial occupations and learn the

42. ka-shemesh marpe bi-chnafea / li-sveat mayim et zorachat / ken rifut goy yom ahavat yasher / bi-lvav tsadikim mitlakachat 43. Mal. 4:2. 
rustic virtues of the countryside. Grégoire writes exultingly of this hope for the future in a passage that epitomizes his agricultural romanticism:

The rustic tasks will then call the Hebrew to our fields, once watered by the blood of his forefathers, and which at that time will be watered by his sweat; he will leave his manor to breath the pure air of the hills: soon stimulated by interest, his once-soft arms will be strengthened by exercise, and this physical improvement will bring moral improvement too, for the first of arts is also the first in virtue. 44

of course, their was little real prospect of Jews becoming farmers upon their emancipation, despite the lifting of the legal ban on their owning land. But the symbol of the Jewish farmer caught the imagination of those who envisioned emancipation. It was a symbol of freedom, of self-sufficiency, of dignity and moral purity. In this way one understands the otherwise incongruous Jewish identification with the peasantry. One makes sense both of Ensheim's depiction of Old Regime injustice, where "a man worked on his field / while the one who did not work ate of

44. Grégoire, 124. 
his fruit," 45 and of revolutionary equity, according to which the farmer "will be sated with the fruit of his labor [me-amalo yishba]." Ensheim identifies with the farmer's aspirations, which he summarizes in the following verses: "The man of the earth plants his vine; / he will rest and hope to make his fruit."46 Again, the composer turns to the Bible for his agricultural imagery. The reference is to Isaiah's "Song of the Vineyard," 47 in which the prophet describes a farmer who planted a vine and "looked for it to yield grapes." The cultivator in Isaiah's parable yielded only wild grapes, since God was angry at the "vineyard," which symbolized the house of Israel turned unjust. In Ensheim's canticle, however, "the hope of the nation will not be disappointed [lo tikazev tikvat am]," and the vine will bear fruit, for "an understanding people will provide its shelter [yasim anshei da'at machsehu]."

At this point one can see that the Hebrew "Marseillaise," among other things, functioned as a lesson in citizenship. Through the use of familiar and sacred imagery, Ensheim attempted to inculcate in his coreligionists a republican understanding of history, an idea of the aristocratic enemy, and an explanation of

\footnotetext{
45. ya'avod ish sadehu / va-asher lo amel bo yochlenu 46. ish ha-adama shorek notea / yishkot ve-yikav la'asot pirehu 47. Isa. $5: 2$.
} 
France's current struggles. He used Biblical metaphors to represent the virtues of citizenship such as sensibilité and transparency, and to articulate the sacred principle of regeneration. The pedagogical experiment continued as the composer endeavored to define freedom and its concomitant responsibilities. Ensheim's explanation of freedom is partly negative. "The voice of the taskmaster is no more," 48 his song proclaims. And later, borrowing a phrase from Ecclesiastes, Ensheim has his brethren sing, "There is no ruler to imprison the spirit."49 But the emergence from slavery, he reminds his coreligionists, entails the duties of freedom. The legislators of France will define these new responsibilities. It is they who, in their Solomonic wisdom, "will guide us on the paths of righteousness."50 Freedom implies obedience to good laws, as the congregation sings:

Arise, brothers! Recount the law!

Take courage! Do as the law prescribes!

The law of the land is our protection.

For we have entered into a covenant of brotherhood.51

48. kol nogesh einenu, Job 3:18.

49. ein shalit lichloa et ha-ruach, Eccl. 8:8.

50. u-v-magle mishor yadrichunu, Cf. Prov. 4:11.

51. kumu achim u-tnu torah / hitchazku va-esu ka-mitsvah / dat ha-aretz lanu mishmaret / ki banu bi-vrit ha-achvah 
This passage defines a certain idea of the relationship between law and fraternity. The law only protects if it is bolstered by a "covenant of brotherhood." Under the old Regime too the Jews had submitted to the law, but it was a law without fraternity, hence devoid of protection. Today, Ensheim assures his Jewish compatriots, all Frenchmen are brothers. Thus he rails against those who would reject national fraternity: "Be ashamed and confounded of your ways."52 Ensheim directs this scolding toward "those who sow discord among brothers," and advises them, following the Proverbs, "It is an honor for you to end your strife." 53

of course, the idea of fraternity had a special meaning for the Jews, so long excluded from the "family" of Frenchmen. Fraternity signified something that had previously been missing in relations between Jews and Christians: trust. The Revolution, in its determination to break down the barriers that once separated Frenchmen, was willing even to embrace the Jews, the most marginal, the most "other" of peoples. But fraternity meant nothing without the promise of eternal durability. To prevent the euphoria of the moment from degenerating into

52. boshu hikalmu mi-darchechem Cf. Ez. 36:32, "Be ashamed and confounded of your ways, 0 house of Israel." 53. kavod lachem shevet meriv, Prov. 20:3. 
factionalization and selfishness, the Revolutionaries had consecrated a sacred institution: the oath of loyalty to the nation. One year prior to the festival at Metz, the Jews had taken the civic oath as a precondition of their admission into active citizenship. Patriotic zeal prompted them to repeat this oath, and the victory festival provided them with an audience for this renewal of their solemn pledge. The Jews of Metz knew that their Christian neighbors had long mistrusted them, and that a popular belief circulated by which a Jewish oath could not be considered valid.54 Nevertheless, they made a sacred oath to the "inhabitants of the land" and cited among their "witnesses" "the altar of the covenant between us [ed mizbeach ha-brit beinotenu]."

Just as the fraternal oath promised eternal loyalty, Ensheim's hymn envisioned the eternal durability of the French nation. Accordingly, the congregation sings to the

54. Grégoire, for examples, claims, "The false oaths (Les parjures) do not make an imprint on their consciences, for God erases them on the Day of Atonement...." Later he asks rhetorically, "If their honesty were not well subject to caution, would so many precautions have been taken, so many treatises written, especially in Germany, on how to have [the Jews] take oaths, which, despite this, are well known to be insufficient for giving rise to trust?" Essai, pp. 87,88 . 
tsadikim, the "righteous ones" of the French nation, "For your goodness you will be praised / As long as the heavens are above the earth."55 Again a Biblical passage is recalled, for this is the same promise of eternity that God makes to the Children of Israel in the book of Deuteronomy. In return for obedience to his law, the Almighty pledges "that your days and the days of your children may be multiplied in the land which the Lord swore to give them as long as the heavens are above the earth."56 Thus the French nation is as durable as the covenant between God and the Chosen People. Yet another metaphor for eternity is used to express the perpetual fame of the "righteous ones" who founded the new French nation. "Blessed be you, men of integrity. / You will be praised unto the last generation," Ensheim's chorus sings. "Behold! You have established a monument unto yourselves. / Your name will be eternal like the moon." 57

By integrating Biblical symbolism into his text, Ensheim not only provided a means for traditional Jews to

\footnotetext{
55. ekev tov tihiyu lithilah / ki-mei shamayin al ha'aretz 56. Deut. 11:21.

57. shem yikon olam ka-yareach The image of the everlasting moon is taken from Psalm 89, in which the throne of King David "will be eternal like the moon [ka-yareach yikon olam]." Ps. 89:38.
} 
construe the radically new events of Revolution and emancipation. Through a kind of Biblical republicanism, he sacralized the values of the new society into which his people were suddenly to be integrated. Mona Ozouf has argued that the chief purpose of the Revolutionary festival was to sacralize new social values.58 This was certainly the case in the Jewish celebrations at Metz. For every value that it represented, the text of the Ensheim's canticle gave Biblical justification. The overthrow of the monarchy was as legitimate as the smashing of the altar of $\mathrm{Ba}$ 'al. The present battles were likened to the heroic struggles of the early Israelites, and at the same time confirmed the prophets' apocalyptic predictions. Aristocrats were not simply unjust; they were sinners. Sensibilité, transparency, rustic purity and fraternity were not merely the values of the day; they were the sacred demands of God. One must not forget that, for all its republican sentiment, the Hebrew "Marseillaise" was a prayer. While praising the human achievements of the righteous Revolutionaries, Ensheim nevertheless viewed the events of his day as the work of the Almighty. Thus his congregation sang in thanksgiving, "0 awesome God on high, God of all creation. / You have done wonders unto us."59 And further:

58. Ozouf, 262-282.

59. nora elyon al kol notsar / niflaot elenu asita 
To the wind you give weight, to the sea its bounds. Your hand has given rhythm to everything. From darkness you have made processions of light. And you have called order out of chaos. 60

Even the legislators of France required divine inspiration; and so the Jews of Metz urged God:

Shine your face upon the righteous.

They will seek the good of the nation.

For you contribute the truth. 61

The profound religiosity of the text should not be surprising. There was nothing in the least unorthodox about composing a hymn to the French nation. On the contrary, patriotic prayer among Jews was already an ancient tradition at the time of the Revolution. It was first dictated by the prophet Jeremiah, who conveyed God's message to the Jews living in Babylonian exile: "Seek the peace of the city whither I have caused you to be carried away captive, and pray unto the Lord for it; for in the

60. la-ruach mishkal la-yam chok / katsev la-kol yadcha asata / mi-tsalmavet tahaluchot or / u-sdarim mithu karata 61. haer paneicha li-sharim / yitron eretz ba-kol yidroshu / ki torem atah ha-nchucha 
peace thereof shall you have peace."62 In the second century B.C., Rabbi Hagina, deputy to the high priest in Jerusalem, formulated what would be the authoritative rabbinic position regarding patriotic prayer: "Pray for the welfare of the government, since but for fear thereof, men would swallow each other alive."63 There is nothing in either the Biblical text or the rabbinic commentary that dictates the form patriotic prayer is to take, and a passionate devotion to the country whither the Lord caused the Jews "to be carried away" is by no means required. The story of patriotic Jewish liturgy in eighteenth-century France, however, shows an attitude vis-à-vis the nation that far surpasses the mere fulfillment of religious duties.

The earliest patriotic service among French Jewry took place in a Bordelais synagogue in 1706, on the occasion of the birth of one of the royal princes. 64 Although no copy of that service is known to exist, many expressions of patriotic prayer survive in printed form. Composed in Hebrew and translated into French for Gentile audiences, these odes, canticles, hymns, "compliments" and benedictions corresponded to critical moments in the life

62. Jer. 29:7.

63. Avot $3: 2$.

64. Arthur Hertzberg, The French Enlightenment and the Jews (New York: Columbia University Press, 1968), 203. 
of the monarchy -- the illness or death of a king, the queen's pregnancy, royal births, military victories and declarations of war and peace.

The Jews of Metz, among their Ashkenazi coreligionists in eastern France, were especially prolific in their composition of "occasional prayers" for the royal family. Ironically, it was the privileged status of the Metz Jewish community under the old Regime that established the tradition which would one day enable the emancipated Jews to celebrate the death of privilege. Taking advantage of their permission to participate in royal festivals, the Jews of Metz celebrated the birth of the dauphin in 1731 . They illuminated and decorated their quarter, organized a procession of elders and community officials in full festival dress, and composed a canticle for the occasion.65 Even more elaborate Jewish festivities took place in 1744 when Louis XV arrived in Metz to support his troops in the war against Austria.66 At this festival the chief rabbi presented Louis with a Compliment au Roy that compared him to the old Testament kings and recognized him as anointed

65. Ab[raham] Cahen, "Une Fête nationale à Metz," in La Vérité israélite 8 (1862): 372-377.

66. [Jacques Balthus], Journal de ce qui s'est fait pour la Réception du Roy dans sa ville de Metz le 4. Août 1744. Avec un Recuëil de plusieurs Pièces sur le même Sujet, \& sur les Accidens survenus pendant son Séjour. Metz, 1744. 
by God. When the sovereign fell gravely ill during his stay at Metz, the rabbi composed special prayers for divine intercession, and the city's Jews offered prayers of thanksgiving when the king recovered.67 The Jewish subjects similarly prayed for their monarch's health during his final illness in 1774, and publicly mourned his death that same year. Immediately afterwards, and in recognition of continuous sovereignty, they celebrated the accession to the throne of God's newly anointed successor to the wellbeloved king. 68

67. Compliment au Roy fait par le Rabin des Juifs de Metz. Metz, 1744; Déliberation concluë dans l'Assemblée générale des Syndics \& Communaute des Juifs de Metz, pour les Prières publiques, composées par le Rabin, \& ordonnées etre dites soir \& matin, après 18. Pseaumes de David, aux fins d'obtenir de Dieu le Recouvrement de la Santé de Sa Majesté LOUIS XV, Roy de France \& de Navarre, sa Conservation, de celle de Sa Majesté la plus pieuse des Reines, de Monseigneur le Dauphin, \& de la très-auguste Famille Royale, des Princes \& Seigneur de sa Cour, Généraux d'Armées, \& la Bénédiction dans ses Armes, [Metz, 1744]. 68. Traduction de la prière hébrä̈que, composée par le Rabin des Juifs de Metz, pour être récitée soir \& matin, \& même pendant la nuit dans la Synagogue, après le dix-huit Pseaumes de David, \& autres prières publiques et extraordinaires, qui ont été enjointes par délibération 
Jewish fulfillment of Jeremiah's prescription was not limited to prayers for the king, however. The queen as well, especially during her pregnancies, was the subject of several liturgical compositions. Her Jewish subjects prayed for the "happy delivery" of a royal scion, preferably a dauphin, but also concerned themselves with the queen's health during labor, asking God to exempt her from the curse of Eve and relieve her from the pain of childbirth.69 These latter compositions, at least in their

expresse de la Communauté, pour obtenir de Dieu le rétablissement de la santé du Roi, Metz, [1774]; Traduction d'une prière hébraïque, composée par le Rabin des Juifs de Metz, \& par eux récitée dans leurs grande synagogue jusqu'au neuf de mois de Juin inclusivement, pour le repos de I'Ame de Louis XV, Roi de France, de glorieuse mémoire, Metz, [1774]; Traduction d'une Cantique hebraïque, composée par le Rabin des Juifs de Metz, à l'occasion de l'avénement au Trône de Sa Majesté régnante; \& exécuté en musique dans leurs grande Synagogue, par leurs Chantres, le 9 Juin 1774, Metz, [1774].

69. Traduction de la prière hébraïque, ajoutée par les Juifs de la synagogue de Metz aux Psaumes et prières particulières qu'ils font journellement pour l'heureux accouchement de la Reine, [Metz, 1778]; Traduction de la prière hébraïque, récitée journellement, après les Pseaumes, dans la Synagogue des Juifs de Metz, pour 
French versions, were probably the work of Isaïah Berr Bing, who would later translate Ensheim's Hebrew "Marseillaise." And it is certain that Bing was responsible for the canticle of 1781, which celebrated the "double miracle" of the dauphin's birth and a French naval victory over the English. 70

When seen in the context of its long history, Ensheim's canticle is less of an enigma. While the values articulated in the text are truly revolutionary, the form of patriotic acclamation is quite traditional. Moreover, as we have seen, each republican principle is shown to be sanctioned or even required by the Jewish religion. The effect is the appearance of absolute compatibility between Revolutionary values and traditional Judaism. It must be emphasized, in order to understand the need for such an impression, that during the age of Revolution devotion to

I'heureux accouchement de la Reine, \& envoyée par leurs Syndics aux Synagogues particulières du Département, avec invitation expresse de se conformer à celle du chef-lieu de la Communauté, Metz, 1781.

70. Traduction de l'Hymne ou Cantique Hébraïque, que les Juifs de Metz ont récité, \& fait exécuter en musique dans leurs Synagogue, le 18 Novembre 1781, jour de réjouissance faite pour la naissance de Monseigneur le DAUPHIN, [Metz, 1781]. 
the Jewish tradition was by itself considered an obstacle to citizenship. To be sure, the Revolution exerted a homogenizing force that did not merely target the Jews. Convinced believers in the principle of indivisibility, Revolutionaries abhorred all "particularism" as narrowminded self-interest and a reversion to feudalism. They demanded a single loyalty from all citizens: the nation. Under these circumstances, the conservation of any nonrepublican identity was an arduous task. For the Jews, the pressure to cast off their history was even more acute, since their "traditions" were considered by definition retrograde. The discourse of emancipation revolved around a single question: Were the Jews virtuous enough to be French citizens? The enemies of emancipation answered "no," and the advocates of Jewish citizenship referred to a hypothetical future when the Israelites would reach the moral level of their compatriots. The Jews were to "rise" to citizenship. Their traditions were seen as an historical yoke to be shaken off. To the extent that they succeeded in becoming Frenchmen, it was implied, they would attenuate their attachment to their Jewish heritage. Emancipation implied a sort of conservation of cultural identity, by which the more "French" the Jews became, the less "Jewish" they would be. Even the most generous advocates of Jewish rights, Abbé Grégoire foremost among them, ridiculed the religious beliefs of the Jews, and did not attempt to conceal his hope that regeneration would 
lead to conversion. Thus he writes, "The complete religious freedom accorded to Jews will be a great step toward reforming, and I dare say it, toward converting them. " 71

Under these circumstances, the Jews were forced to maintain a delicate balance. They experienced the pressure to become "regenerated" as citizens, but naturally wished to conserve their ancient heritage. They had not only the Christian inhabitants of France to convince; they had themselves to convince as well. In this context, the Hebrew "Marseillaise" can be seen as an attempt to synthesize republicanism and Judaism, to espouse the former without renouncing the latter. In the text itself, as we have seen, this was accomplished through a kind of Biblical republicanism, by which the Jewish religion "authorized" republican values. In this way Ensheim rejected Grégoire's logic of emancipation. Asked to choose between his ancient tradition and the duties of modern citizenship, he refused to choose, and indeed devised a solution by which the latter appeared to be decreed by the former. In order to espouse the values of Revolution without rejecting their past, Ensheim and his coreligionists set out to sacralize the Revolution, to give it the benediction of the rabbis, to incorporate it into the ancient tradition of the Hebrews. This sort of appropriation through sanctification

71. Grégoire, 134. 
was achieved not only in the text of Ensheim's hymn, but in other aspects of the Jewish celebrations as well. It is most significant, in this respect, that the rabbi of Metz invited the defenders of Thionville into the synagogue. There, in the sacred space of the house of prayer, with the Torah on display in the holy arc, the spiritual leader of the Jewish community consecrated a patriotic victory. When the rabbi presented Mayor Rolly with a "civic crown," he performed a kind of coronation. Like a bishop inaugurating a prince, he sacralized a civic office. Finally, the joining of the Revolution to the Jewish faith was achieved in song. By playing and singing the "Marseillaise" inside the house of worship, the war-cry of the republic was transformed into a hymn to God. And by performing, in the sacred language, a Jewish version of the patriotic anthem, the Jews suggested the perfect compatibility between love for the patrie and fidelity to their ancient tradition.

As to the content of the Ensheim's song, only a French translation made this comprehensible to the Christian observers. After all, what good was a hymn to the Fatherland if one's compatriots could not understand it? As in the case of its composition, very few individuals were qualified to translate the Hebrew text into French. Indeed, Isaiah Berr Bing, who accomplished this task, was perhaps the only Jew in Metz capable of writing in French. Like Ensheim, Bing was one of the great intellectuals of 
the Ashkenazi communities. Although he considered himself "orthodox" in his beliefs, he was known as the most "enlightened" Jew in Metz. Bing's scholarly credentials were impressive. He had read the work of Moses Mendelssohn, and in 1786 translated his principal work, Phädon, into Hebrew. In 1787 he defended traditional Judaism against an anti-semitic attack that had been published the previous year, 72 and in 1790 he reworked his initial arguments in a mémoire for the National Assembly. 73 Like Ensheim, Bing was influenced considerably by the ideas of the Jewish Enlightenment, or Haskalah, that were most prominent in Berlin. He proclaimed his commitment to progress, and saw the need to incorporate Enlightenment into the Jewish religion. His conviction that the Jews could be "regenerated" certainly influenced Abbé Grégoire, with whom Bing maintained close contact. Like Grégoire, Bing believed that the Jews of his day were a degraded people, materialistic and cowardly, but that they could remedy these deficiencies, that they could "regenerate"

72. [Isaïah Berr Bing], Lettre du Sr.I.B.B. Juif de Metz, à l'auteur anonyme d'un écrit intitulé: Le cri du citoyen contre les juifs de Metz, Metz, 1787.

73. [Isaïah Berr Bing], Mémoire particulier pour la communauté des Juifs établis à Metz, Rédigé par Isaac Ber[r]-Bing, I'un des Membres de cette Communauté, Paris, 1790 . 
through equal participation in social and political life. 74 Familiar with the current discourse of regeneration and versed in the idiom of Enlightenment, then, Bing was the ideal candidate for translating Ensheim's patriotic sentiments into the language of the French republic.

It would be redundant to explicate the French translation in detail. Since the principal ideas in Ensheim's original hymn have already been discussed, it seems most appropriate simply to cite Bing's version in its entirety. As a transparent republican text, it is, after all, self-explanatory:

Tyranny is finally subdued. It's scepter has been shattered against the republican shield, and our defenders march triumphantly over the wreckage of conquered enemies.

Since the dawn of Liberty, the despots have prepared new irons for us; they have long schemed

74. Hertzberg, 329-338; E. Tcherikower, Yidn in Frankraikh, vol.2 (New York: Yiddish Scientific Institute, 1942), 1819. 
new means of subjugating us. 75 They came, and devastation followed in their tracks.

But, oh wonder! Oh marvel! Scarcely had their numerous battalions taken a few steps into our territory, when the sight of warriors armed for the Fatherland made them recoil in terror; they fled, carrying shame and opprobrium with them.

Generous Citizens! You fight for Equality and for Liberty: She has consecrated your arms in her defence; she has made you forever invincible.

Tremble, oppressors! 76 Tremble under your gilded panels; our songs of joy will remain in our hearts and will ignite them for Divine Liberty.

And you, denatured children of a tender and indulgent mother.77 What is left of you and your sinister plots now, if not the shame of having

75. Cf. the "Marseillaise": "Que veut cette horde d'esclaves, / De traîtres, de rois conjurés? / Pour qui ces ignobles entraves, / Ces fers dès longtemps préparés?" 76. Cf. the "Marseillaise": "Tremblez, tyrans!" 77. Cf. the "Marseillaise": "Tous ces tigres qui, sans pitié, / Déchirent le sein de leur mère!" 
conceived them and the despair of their not having succeeded?

And you too, you who use religion as a pretext for your useless passions! Your hope has vanished; for your destructive projects you will receive only the indignation of upright and sensitive hearts.

People of France! Your representatives assemble in the sanctuary that you have opened to them; they will give you laws founded upon the immutable bases of nature and justice.

Just as the vivifying rays of the sun fertilize a field soaked by the dew of the sky, so the health of a nation is brought about the moment the love of Liberty animates the souls of the strong and virtuous.

It is no more, this time when a dominator, terrible in his wrath and capricious in his favor, often punished without offense and rewarded without reason! The law reigns: it alone shall punish crime and reward virtue. 
It is no more, this time when the fruit of the field made fertile by the efforts of the peaceful cultivator was the share of the idle ones who oppressed him! The law reigns: it protects property and its legitimate owners.

It is no more, this time when fanaticism, nourished by a few bloody priests, sowed hatred and discord among children of the same father! 78 Beneficent philosophy has embraced all men in the bonds of fraternity.

The law judges the man according to his actions; he is accountable for them to his Fatherland and his fellow citizens; but his beliefs are his own, and for them he is answerable only to his creator.

Oh! Israel, for too long cruel intolerance has persecuted you; it almost overwhelmed you, and despair took possession of your heart. Awake to

78. Cf. Grégoire, "Children of the same father, rid yourselves of all pretext for the hatred of your brothers, who one day will be reunited in the same cradle." Essai, 177. 
the strains of Liberty, the days of your happiness have arrived.

The magnificent lion loses his strength and his noble pride the moment he no longer breathes the free air of the forests; and man sinks into vice and loses his dignity under the shameful yoke.

Open the records of history, consult the annals of the world, they will show you that we have always followed the progress of peoples wherever we have been treated with humanity. 79

Burst forth, oh my brothers! in thanksgiving; the sacred land in which we live has become our Fatherland; the laws of the French Republic are our laws too; a holy alliance has embraced us in the great family of free men.

\begin{abstract}
79. Cf. Bing, "When one compares...the Jewish merchant of America, of London, of Amsterdam and of Berlin to those whom public opinion disdains among us, one will be persuaded that the Jew becomes patriotic to the extent that the patrie becomes beneficent towards him." Mémoire particulier pour la communauté des Juifs établis à Metz..., Paris, 1790.
\end{abstract}


Citizens! Bear witness to our solemn oath; we renew it today before this Altar, we swear to renounce life itself before we renounce the imprescriptible rights of man; Yes! we will sooner perish than bow our heads to the yoke of slavery.

Sovereign Master of the Universe! God Almighty! How great are your marvels! How sublime! What mortal is worthy to speak of them? The countless globes that revolve in boundless space are the result of your will; they continually follow the course that you have shown them. It is you who have imparted motion to the wind; It is you who contain the ocean within its bounds. Chaos has heard your voice, and order and symmetry have developed in your care.

Deign, eternal God! Deign to shed your wisdom upon the representatives of this generous people; may the laws that they make for us be inspired by it.

Legislators, you have erected a monument more durable than bronze: the most remote posterity, praising your good deeds, will pronounce your names with the fondest gratitude. 
France! Delightful country! For those who have contemplated your downfall, terror now keeps them far from your cities. Enjoy the peace, be joyful of the happiness of your children and rest in their invincible arms.

The Biblical images that fill the Hebrew "Marseillaise," it will be noted, are either entirely absent or changed beyond recognition in the French version. one reason for this discrepancy is clear. The French version employed the language of republicanism because its audience was republican. The Hebrew text served the needs of the Jews themselves, for whom the idiom of republicanism was foreign and abstract. The familiar imagery of the Holy Scriptures provided the Jews with a vehicle for comprehending the dizzying events in which they found themselves. It endowed these events with sacred significance, and enabled the Jews, through a peculiar use of ancient metaphors, to bind their history to the destiny of the patrie. The French text served as the official expression of Jewish patriotism. Its audience was the Gentile community of Metz in particular and of France in general, and its intention was very clearly to convey a specific message: that the Jews, despite popular suspicions about their loyalties, embraced Frenchmen as 
"brothers," supported the cause of Revolution, and were prepared for the duties of citizenship.

of course, a more direct translation of the Hebrew text would have been sufficient to demonstrate Jewish loyalty to the nation, as the original version was undeniably full of patriotic zeal. And yet, Bing found it necessary to do violence to Ensheim's song, to eliminate systematically all its Biblical allusions. The "wicked reign" that conjured images of idolatrous Babylon he translated simply as "tyranny." Aristocrats were no longer likened to false prophets "who wear cloaks of fur," as Bing chose to depict them simply as those who live "under gilded panels." In his praise of the legislators of France, he removed the psalmodic formula, "Your name will be eternal like the moon," and replaced it with the neutral and unallegorical acclamation, "[Y]ou have erected a monument more durable than bronze." The assurance that the representatives of the nation, in imitation of Solomon, would "guide us on the paths of righteousness" was changed to read, "[T] hey will give you laws founded upon the immutable bases of nature and justice." And Bing simply disposed of all obvious Biblical references, such as Ensheim's metaphor for the fall of the Old Regime, "Behold, the altar of Ba'al has been broken down!"

In his "translation" of Ensheim's text, then, Bing purged it of all its Biblical allusions. His only reference to God is more a deistic rendering of a supreme 
Being than the image of an old Testament God who punishes, rewards, and sees into the hearts of his creatures. Otherwise the translation is almost devoid of its original Jewish specificity. Apart from a single reference to "Israel," there is almost nothing recognizably Jewish in the French translation. Like so many other texts of its type, the official expression of Jewish patriotism depicts a world divided between patriots and traitors, partisans of liberty and slaves of tyranny. As conspirators plot against the Revolution, a free people, guided by courage, justice, and above all "upright and sensitive hearts" takes a solemn, fraternal oath to die if necessary in the protection of the rights of man. The "translator" seems to have taken Ensheim's text, rich in Biblical symbolism and full of religious devotion, and turned it into a republican cliché .

And yet, Bing is not to blame. His French "translation" is the logical result of the demands that republicanism placed on its adherents, particularly its Jewish ones, and indeed grows out of the same set of impulses that inspired Ensheim to compose the Hebrew "Marseillaise." Republican ideology demanded transparency; it required an unmediated relationship between the individual and the nation. This entailed the elimination of all barriers to mutual understanding. The republic had no tolerance for unauthorized use of allegory, as it might not be immediately apprehended by all citizens. A metaphor 
from the 0ld Testament might well be obscure, that is to say opaque, to those who did not belong to the Jewish community. It would reward the particularist concern for one's ethnicity at the expense of one's compatriots. The text that Bing translated into French had to be transparent to all citizens. Paradoxically, this Revolutionary drive for indivisibility was powerful enough to censor even the most zealous expression of an ardent patriot.

Significantly, what happened to Ensheim's words is analogous to what the advocates of emancipation hoped would happen to the Jews themselves. And the pressure that Bing felt to purge Ensheim's text of its obscurities is analogous to the pressure that the Jewish community experienced to rid itself of its "particularism." Like Bing's "translation," versed in the idiom of republicanism and full of unselfish concern for the French nation, the Jews were supposed to be regenerated. Like the text itself, they were supposed to become less "Jewish" and more transparent. This Revolutionary pressure toward indivisibility helps to explain why the Jewish celebrations at Metz in 1792 were not repeated during the years of the First Republic. Festive expressions of Jewish patriotism had been numerous under the old Regime, and were to reappear in even greater strength and number under Napoleon. But for the years of the Revolution itself we have evidence of the Hebrew "Marseillaise" at the fête 
civique in Metz and nothing else of its kind. The absence of comparable manifestations is all the more remarkable in light of the abundance of Revolutionary festivals in general. At a time when French Christians were celebrating their freedom in countless festivals, why did the Jews, whose situation had been even more dramatically improved by Revolution, fail to repeat the festivities at Metz?

One reason is clear: during the Terror of 1793 and 1794 the government persecuted traditional religious expression. Synagogues as well as churches were rededicated "temples of Reason," and religion was forced to go underground. This phase, however, was relatively short, and does not explain why Jewish festivals could not have reappeared under the Directory. A more convincing explanation, it seems, is that the events at Metz could not have repeated themselves because these Jewish festivities had been precisely a celebration of the dissolution of the Jewish community.

In its attempt to fashion an indivisible nation, the Revolution had set out to abolish all corporative bodies as unreasonable relics of the old Regime. Even the greatest defenders of Jewish rights never for a moment considered allowing the Jews to retain their communal structures -their particular laws, police, courts, administrative bodies, syndics and elders -- following emancipation. The legislators of France had no intention of exempting the Jews from what they would require of all citizens. Even 
the leaders of the Jewish communities and beneficiaries of the old structures quickly dropped their initial demands for communal autonomy and accepted what the comte de Clermont-Tonnere epitomized as the conditions of emancipation: "It is necessary to refuse the Jews everything as a nation and to give them everything as individuals. " 80

Accordingly, any further Jewish celebrations would be a reversion to the very particularism that their patriotism demanded them to resist. The only sort of Judaism acceptable to the republic was one stripped of its communal aspects and reduced to a belief, a matter of conscience between the believer and his God. Bing summarized this condition in his French version of the cantique: "The law judges the man according to his actions; he is accountable for them to his Fatherland and his fellow citizens; but his beliefs are his own, and for them he is answerable only to his Creator." Officially, then, Judaism was to be individualized. The Jews were to relegate their ancient communal identity to a private, secondary status, and to privilege a new, public identity as French citizens.

80. Opinion de M. le comte Stanislas de Clermont-Tonnerrre, député de Paris, le 23 décembre 1789 (Paris: 1789), 13. Cited in Patrick Girard, Les Juifs de France de 1789 à 1860: de l'émancipation à l'égalité (Paris: Calmann-Lévy, 1976), 51 . 
Despite the disorientation that such a revision entailed, the Jews were to receive in return equal civil and political rights, as well as final acceptance into the "great family of free men." Under these circumstances, the exchange seemed well worth celebrating. 